\title{
STUDI LITERATUR : ANALISIS PRAKTIK PEMBELAJARAN FISIKA DI SMA UNTUK MELATIH KETERAMPILAN PEMECAHAN MASALAH
}

\author{
Churoni Fryda Hajar Ayudha1, Woro Setyarsih² \\ 1 Jurusan Fisika, Universitas Negeri Surabaya, Surabaya \\ 2Jurusan Fisika, Universitas Negeri Surabaya, Surabaya \\ e-mail: 1'churoni.17030184016@mhs.unesa.ac.id 2worostyarsih@unesa.ac.id
}

\begin{abstract}
Abstrak
Pemecahan masalah (problem solving) merupakan salah satu keterampilan yang wajib dimiliki peserta didik di abad 21, terutama pada mata pelajaran fisika. Penelitian ini bertujuan untuk menganalisis indikator yang digunakan pada keterampilan pemecahan masalah, menganalisis praktik pembelajaran (model, media pembelajaran, dan materi) fisika yang dapat melatih keterampilan pemecahan masalah peserta didik tingkat SMA, dan menganalisis penyebab peserta didik kesulitan memecahkan masalah fisika. Metode penelitian ini menggunakan studi literatur dengan analisis bibliometrik. Data penelitian diperoleh dari 21 artikel yang diseleksi melalui Publish or Perish yang terindikasi Scopus dari tahun 2016-2020 dalam bentuk article journal dan conference paper. Hasil analisis data menunjukkan bahwa 15 penulis artikel memenuhi empat indikator keterampilan pemecahan masalah menurut $G$. Polya, yaitu memahami masalah, merencanakan penyelesaian, menyelesaikan masalah sesuai rencana, dan melakukan pengecekan kembali terhadap semua langkah dan melakukan evaluasi. Berdasarkan hasil kajian studi literatur didapatkan beberapa rekomendasi model pembelajaran yang dapat melatih keterampilan pemecahan masalah, yaitu model pembelajaran dengan pendekatan saintifik yang menekankan pada student centered learning dan bantuan media teknologi, seperti PBL, pembelajaran inkuiri, PjBL, dan pembelajaran kolaboratif, terutama pada materi mekanika. Hasil lain didapatkan faktor utama penyebab peserta didik kesulitan memecahkan masalah fisika adalah guru masih menggunakan metode pembelajaran konvensional.
\end{abstract}

Kata kunci: Keterampilan pemecahan masalah, pembelajaran fisika, bibliometrik.

Problem solving is one of the skills that must be possessed by students in the 21st century, especially in physics subjects. This study aims to analyze indicators of problemsolving skills, analyze the learning practices (learning models, learning medias, and materials) of physics that can train the problem-solving skills of high school students, and analyze the causes of problem-solving difficulties faced by students. This method of research used literature studies with bibliometric analysis. The research data taken from 21 articles selected through Publish or Perish in the Scopus database indicated from 2016-2020 in the form of article journals and conference papers. The results of the data analysis shows that the 15 authors of the article qualified four indicators of problem-solving skills according to G. Polya, namely understanding problems, planning solutions, solving problems as planned, and rechecking all steps and conducting evaluations. Based on the results of the study of literature studies obtains several recommendations of learning models that can train problem solving skills, namely learning models with scientific approaches that emphasize on student centered learning and technology media assistance, such as PBL, inquiry learning, PjBL, and collaborative learning, especially in mechanical subjects. Another result obtains the main factor that causes students difficulty solving physics problems is that teachers still use conventional learning methods.

Keywords : Problem solving skills, physics learning, bibliometric. 


\section{Pendahuluan}

Perkembangan ilmu pengetahuan bidang sains dan teknologi pada era abad 21 semakin pesat, sehingga menuntut sistem pendidikan yang semakin maju. Assessment and Teaching of 21st Century Skills (2018) pada artikel jurnal Lolanessa et al (2020) mengkategorikan keterampilan abad 21 dalam 3 keterampilan, yaitu: (1) cara berpikir, seperti kreatif, inovatif, kritis, mampu memecahkan masalah, bijak mengambil keputusan dan melakukan pembelajaran.; (2) keterampilan dalam berkomunikasi dan bekerja sama tim; dan (3) keterampilan untuk hidup di dunia, misalnya memiliki kesadaran sebagai warga negara global dalam mengembangkan-hidup dan karir, serta memikul tanggung jawab pribadi dan sosial.

Kemampuan untuk memecahkan masalah khususnya pemecahan masalah kompleks berupa permasalahan nyata dalam kehidupan bermasyarakat, merupakan salah satu keterampilan yang harus dimiliki oleh sumber daya manusia suatu negara. Apabila keterampilan pemecahan masalah masyarakat rendah akan berakibat pada rendahnya kualitas sumber daya manusia negara tersebut (Cahyani. $\mathrm{H}$ et al, 2016; Zunanda. $\mathrm{M}$ et al, 2017). Keterampilan pemecahan masalah menjadi suatu keterampilan penting yang- harus ditingkatkan oleh berbagai tingkat pendidikan, khususnya tingkat pendidikan sekolah menengah atas (SMA) karena pada tingkat ini peserta didik sudah mulai berpikir secara logis, kritis, dan memiliki keingintahuan yang tinggi tentang bagaimana mengembangkan keterampilan pemecahan masalah peserta didik (Azizah, R. et al, 2018).

Pada proses menyelesaikan berbagai permasalahan, peserta didik berupaya menyelesaikan masalah dengan mendiskusikan masalah bersama teman sebaya atau mencari berbagai informasi untuk mendapatkan solusi alternatif yang tepat (Argaw, W. et al, 2019). Hal tersebut menjadi tidak tepat apabila pemberi solusi memberikan sebuah solusi yang menjerumuskan atau bahkan dapat menimbulkan masalah baru (Nusailah, 2015). Oleh sebab itu guru perlu melatih keterampilan pemecahan masalah pada peserta didik, karena kehidupan peserta didik tidak dapat terlepas dari adanya masalah, seperti masalah perkembangan diri, mulai dari pertumbuhan fisik, perkembangan kognitif, dan perkembangan emosi (Cahyani. $\mathrm{H}$ et al, 2016; Nusailah et al, 2015).

Karakteristik peserta didik yang memiliki keterampilan pemecahan masalah yang baik, diantaranya fokus menemukan solusi yang tepat, memiliki pemikiran yang terbuka dengan menerima pengetahuan baru, mencari peluang dalam masalah, mengetahui perbedaan antara pemikiran kompleks dan sederhana, mengidentifikasi masalah secara spesifik, membuat solusi yang adil tanpa merugikan orang lain, mengeksplorasi pilihan dengan mencari cara baru dan logis tanpa membuat masalah aru (Abdulfattah. A et al, 2019; Nusailah et al, 2015).

Pemecahan masalah merupakan suatu proses lengkap bagi peserta didik dalam pembelajaran fisika, karena permasalahan dalam pembelajaran fisika berhubungan dengan konteks kehidupan sehari-hari (Amanah et al, 2017). Peserta didik yang dapat memecahkan permasalahan akan memiliki pengalaman yang bermakna dan tertanam pada memori, yang menjadikan peserta didik aktif dalam kegiatan belajar mengajar (Destalia. L, et al, 2014). Fakta tersebut menunjukkan keterampilan pemecahan masalah merupakan salah satu keterampilan penting yang harus dikembangkan pada pembelajaran fisika (Supeno et al, 2018). Pemerintah telah menetapkan berbagai model dan metode pembelajaran yang dapat melatih keterampilan pemecahan masalah peserta didik (Ratnaningdyah, 2017). Model pembelajaran tersebut harus mendasar pada permasalahan yang membutuhkan penyelidikan autentik, yaitu penyelidikan yang membutuhkan penyelesaian nyata dari suatu permasalahan dengan menggunakan pendekatan pembelajaran yang melatih peserta didik untuk aktif belajar, sehingga dapat merumuskan dan memecahkan permasalahan berdasarkan informasi yang telah diberikan (Destalia. L, et al, 2014; Abdulfattah. A et al, 2019). Serta metode pembelajaran yang dapat meningkatkan perhatian peserta didik terhadap fenomena fisika, akan mempermudah pemahaman terhadap materi fisika (Ratnaningdyah, 2017).

Selain model dan metode pembelajaran diperlukan juga adanya indikator yang digunakan sebagai alat ukur atas pencapaian terhadap tujuan pembelajaran yang sesuai dengan kompetensi dasar. Penelitian ini berfokus pada keterampilan pemecahan masalah, 
sehingga indikator keterampilan pemecahan masalah fisika yaitu terdiri dari 1) memahami masalah, 2) merencanakan penyelesaian, 3) menyelesaikan masalah sesuai rencana, dan 4) melakukan pengecekan kembali terhadap semua langkah dan melakukan evaluasi (Jayadiningrat. M.G. et al, 2018).

Berdasarkan penjelasan yang telah dipaparkan, dilakukan analisis terhadap hasil studi sebelumnya menggunakan metode literatur review dengan analisis bibliometrik tentang keterampilan pemecahan masalah fisika pada peserta didik tingkat SMA selama lima tahun terakhir (2016-2020), yang digunakan untuk mengetahui seberapa jauh perkembangan pemecahan masalah pada pembelajaran fisika. Berbagai artikel tersebut mengungkap tentang rendahnya keterampilan pemecahan masalah pada pembelajaran fisika yang disebabkan oleh peserta didik kesulitan memecahkan permasalahan fisika, sehingga dilakukan berbagai pengembangan praktik pembelajaran yang melatih keterampilan pemecahan masalah pada beberapa materi fisika.

Pemecahan masalah masih perlu diteliti lebih lanjut dan dilakukan upaya untuk melatih keterampilan pemecahan masalah yang merupakan keterbaruan dari penelitian ini. Tujuan dari penelitian yaitu untuk menganalisis indikator yang digunakan pada keterampilan pemecahan masalah yang dijadikan sebagai alat ukur untuk mengetahui tercapainya tujuan pembelajaran, menganalisis praktik pembelajaran meliputi: model dan media pembelajaran, serta materi fisika yang dapat digunakan guru untuk melatih keterampilan pemecahan masalah peserta didik tingkat SMA, selain itu melacak informasi penyebab kesulitan-kesulitan peserta didik dalam proses pemecahan masalah fisika agar guru dapat memperbaiki praktik pembelajaran yang digunakan sehingga peserta didik akan terlatih dalam menyelesaikan permasalahan fisika.

\section{Metode}

Jenis penelitian ini merupakan penelitian kepustakaan (library research) dengan menggunakan metode analisis bibliometrik. Analisis bibliometrik dilakukan dengan melihat persebaran publikasi untuk mengevaluasi kontribusi artikel terhadap kemajuan pengetahuan berbagai literatur menggunakan pendekatan statistika dan dapat memberikan pemahaman yang lebih luas terhadap keseluruhan disiplin ilmu (Yulianingsih. S et al, 2020; Nuryudi, 2016; Suprapto N, et al. 2020). Teknik pengumpulan data penelitian ini menggunakan data sekunder. Data penelitian berupa artikel penelitian terkait pemecahan masalah fisika dan praktik pembelajaran yang meliputi model pembelajaran, media pembelajaran, dan materi. Selain itu, dilakukan analisis mengenai berbagai masalah kesulitan belajar dalam pemecahan masalah pada pembelajaran Fisika di SMA beserta indikator yang digunakan.

Pengambilan data dilakukan sejak bulan Oktober 2020, kemudian dilakukan pengolahan data dan didapatkan 21 artikel terindeks scopus selama 5 tahun terakhir (2016-2020). Berikut alur metode pengumpulan dan pengolahan data yang telah dilakukan:

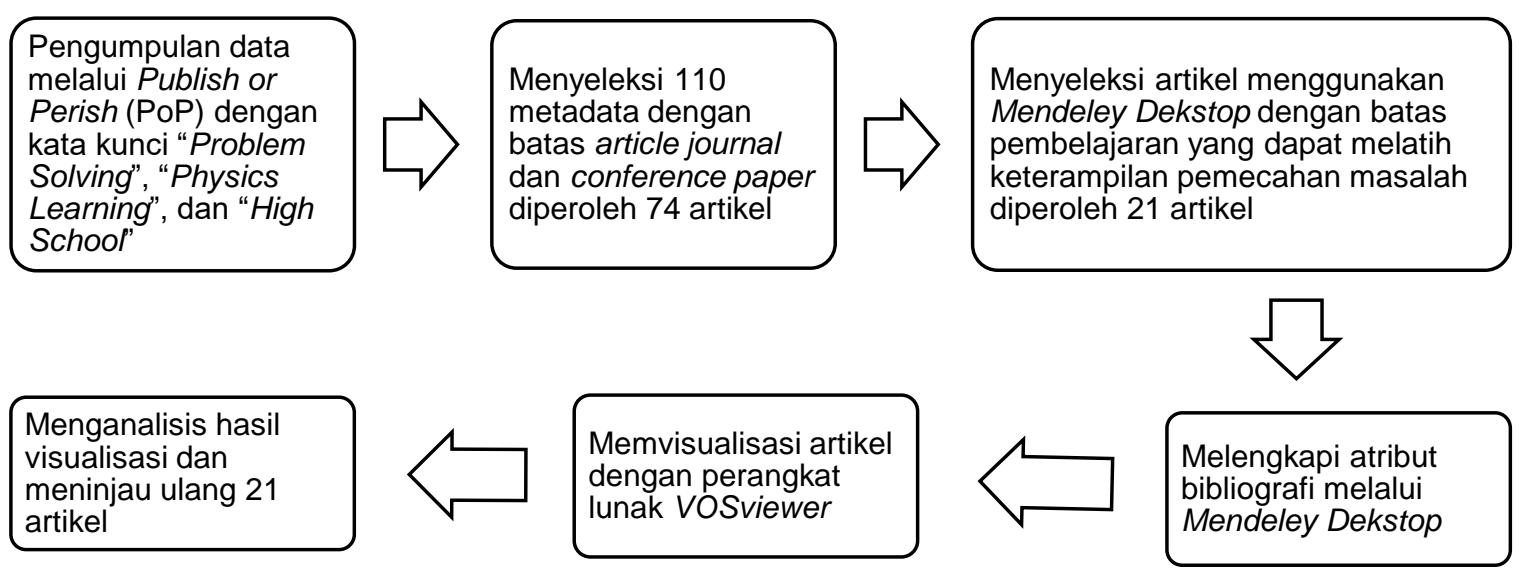

Gambar 1. Metode pengumpulan dan pengolahan data 
Teknik analisis data pada penelitian, yaitu mengacu pada hasil pemetaan bibliometrik dari aplikasi VOSviewer yang menerapkan perhitungan Co-Occurrence. Analisis CoOccurrence mengungkap topik penelitian secara statistik, dengan ketentuan semakin sering terjadi pasangan antar dua kata kunci, maka semakin dekat hubungan antar kata kunci tersebut (Sidiq, 2019). Berdasarkan teknik analisis, diketahui bahwa terdapat beberapa bagian dalam proses pembelajaran yang dapat melatih keterampilan pemecahan masalah seperti: menganalisis indikator yang digunakan pada keterampilan pemecahan masalah, menganalisis penyebab peserta didik kesulitan memecahkan masalah fisika, menganalisis praktik pembelajaran (model pembelajaran, media pembelajaran, dan materi)

1. Model pembelajaran apa yang dapat melatih keterampilan pemecahan masalah?

2. Media pembelajaran apa yang dapat digunakan untuk membantu melatih keterampilan pemecahan masalah?

3. Materi pembelajaran apa yang harus diterapkan untuk membantu melatih keterampilan pemecahan masalah?

\section{Hasil dan Pembahasan}

Hasil penelitian yang didapatkan pada seleksi bertahap menggunakan aplikasi PoP, Mendeley Desktop, dan VOSviewer diperoleh 21 artikel pemecahan masalah pada pembelajaran fisika di SMA. Sebagian besar tujuan dari artikel tersebut adalah untuk melatih keterampilan pemecahan masalah peserta didik menggunakan pembelajaran yang sesuai dengan kajian penelitian masing-masing. Gambar 2 menunjukkan publikasi penelitian pemecahan masalah pada pembelajaran fisika di SMA sepanjang tahun 2016 hingga 2020. Jumlah artikel pemecahan masalah pada pembelajaran fisika di SMA sepanjang tahun mengalami peningkatan dan penurunan (fluktuatif). Artikel mengenai pemecahan masalah pada pembelajaran fisika di SMA paling banyak diterbitkan pada tahun 2019, sedangkan paling sedikit pada tahun 2016. Penjelasan tersebut menunjukkan bahwa pemecahan masalah pada pembelajaran fisika di SMA masih berpotensi untuk diteliti lebih lanjut. Pembaruan pada penelitian ini berfokus untuk mengkaji dan meninjau perihal keterampilan pemecahan masalah dengan metode studi kasus.

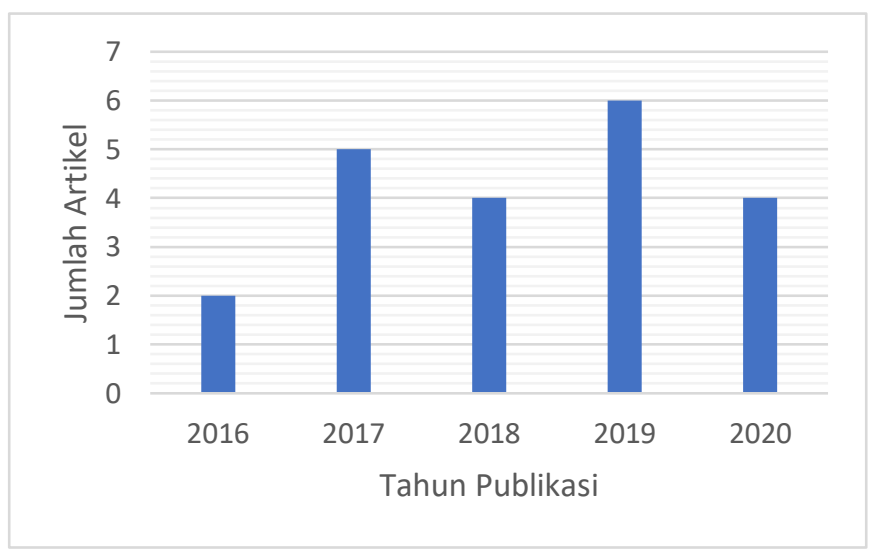

Gambar 2. Publikasi penelitian pemecahan masalah selama kurun waktu 2016-2020

Pengkajian awal pada 21 artikel dilakukan untuk mendapatkan indikator keterampilan pemecahan masalah yang digunakan sebagai parameter keterampilan peserta didik. Peneliti kemudian membagi kata kunci menjadi dua yaitu "indikator" dan "pemecahan masalah" 
supaya lebih mudah untuk mencari temuan penelitian. Menurut Darwin Syah, indikator pembelajaran merupakan capaian terhadap kompetensi dasar yang secara spesifik dijadikan alat ukur untuk mengetahui tercapainya tujuan pembelajaran (Yusuf. B.B, 2018). Sedangkan menurut G. Polya terdapat 4 indikator keterampilan pemecahan masalah, yaitu: 1) memahami masalah, 2) merencanakan penyelesaian, 3) menyelesaikan masalah sesuai rencana, dan 4) melakukan pengecekan kembali terhadap semua langkah dan melakukan evaluasi (Jayadiningrat. M.G. et al, 2018).

Menurut Lestari. P.E. et al, 2019 beberapa aktivitas yang dapat melatih keterampilan pemecahan masalah dalam praktik pembelajaran fisika, yaitu peserta didik memahami permasalahan tentang fenomena fisika yang diberikan oleh guru, peserta didik menyusun rencana untuk menyelesaikan permasalahan, peserta didik menyelesaikan permasalahan sesuai dengan rencana yang telah disusun, peserta didik mengulang kembali setiap langkah dan melakukan evaluasi kebenaran tentang jawaban dari permasalahan tersebut. Berdasarkan pemahaman tersebut, dapat disimpulkan indikator pemecahan masalah dibagi menjadi 4 hal yaitu memahami masalah, merencanakan penyelesaian, menyelesaikan masalah sesuai rencana, dan melakukan pengecekan kembali terhadap semua langkah dan melakukan evaluasi. Berikut disajikan indikator pemecahan masalah yang digunakan pada 21 artikel terpilih.

Tabel 1. Indikator pemecahan masalah

\begin{tabular}{|c|c|}
\hline Indikator & Penulis \\
\hline $\begin{array}{l}\text { 1) memahami masalah, } \\
\text { 2) merencanakan penyelesaian, } \\
\text { 3) menyelesaikan masalah sesuai rencana, } \\
\text { dan } \\
\text { 4) melakukan pengecekan kembali terhadap } \\
\text { semua langkah dan melakukan evaluasi }\end{array}$ & $\begin{array}{l}\text { Rokhmat. J et al, 2019; Rokhmat. J et al, } \\
\text { 2017; Patandean. A et al, 2017; } \\
\text { Olaniyan. A et al, 2017; Kurniawan. A et } \\
\text { al, 2019; Almudi. J et al, 2016; } \\
\text { Aminullah. R et al, 2020; Fitriani. N et al, } \\
\text { 2020; Mason. A et al,2016; Pandaengan. } \\
\text { P et al, 2017; Putra. A et al, 2018; } \\
\text { Shabrina et al, 2018; Iradat. R et al, } \\
\text { 2017; Abdulfattah. A et al, 2019; Retno. } \\
\text { N H D et al, } 2019\end{array}$ \\
\hline $\begin{array}{l}\text { 1) memahami masalah, } \\
\text { 2) menyelesaikan masalah sesuai rencana, } \\
\text { dan } \\
\text { 3) melakukan pengecekan kembali terhadap } \\
\text { semua langkah }\end{array}$ & Jin. Y et al, 2020; Sakhman. L et al, 2019 \\
\hline $\begin{array}{l}\text { 1) memahami masalah, } \\
\text { 2) menyelesaikan masalah sesuai rencana, } \\
\text { dan } \\
\text { 3) melakukan pengecekan kembali terhadap } \\
\text { semua langkah dan melakukan evaluasi }\end{array}$ & $\begin{array}{l}\text { Argaw et al, 2017; Herayanti. L et al, } \\
2020\end{array}$ \\
\hline $\begin{array}{l}\text { 1) memahami masalah, } \\
\text { 2) merencanakan penyelesaian, dan } \\
\text { 3) menyelesaikan masalah sesuai rencana }\end{array}$ & Song. Y, 2018; Raissi. M et al, 2019 \\
\hline
\end{tabular}


Hasil penelitian mengenai keterampilan memecahkan masalah diperoleh dari analisis kata kunci (keyword) pada 21 artikel penelitian menggunakan perangkat lunak VOSviewer, dilakukan untuk menemukan variabel-variabel penelitian mengenai topik pemecahan masalah pada pembelajaran fisika. Berdasarkan pemetaan VOSviewer mengenai pemecahan masalah, dapat ditemukan beberapa parameter keterkaitan antar variabel, yaitu praktik pembelajaran fisika yang dapat melatih keterampilan pemecahan masalah peserta didik di SMA, meliputi model pembelajaran, pendekatan pembelajaran yang sesuai dengan model pembelajaran, media pembelajaran, dan materi fisika. Gambar 3 menunjukkan pemetaan hasil kesamaan keyword artikel pemecahan masalah pada pembelajaran fisika di SMA, diperoleh 8 kelompok (cluster) sesuai warna masing-masing dengan 51 istilah kata kunci yang berkaitan mengenai pemecahan masalah pada pembelajaran fisika. Seleksi kata kunci kemudian dilakukan sesuai tujuan penelitian, yaitu pembelajaran fisika yang dapat melatih keterampilan pemecahan masalah peserta didik.

Dari hasil yang didapatkan, semakin besar bulatan pada suatu kata kunci menunjukkan bahwa kata kunci tersebut banyak digunakan penulis artikel dan memiliki hubungan kuat dengan kata kunci yang lain. Gambar 3 memiliki 3 bulatan terbesar yaitu problem solving, physics education, dan problem based learning (PBL), yang menunjukkan terdapat kaitan antara keterampilan pemecahan masalah pada pembelajaran fisika dengan model pembelajaran problem based learning ( $P B L$ ) atau dapat dikatakan bahwa pembelajaran problem based learning ( $P B L$ ) menjadi salah satu model pembelajaran utama yang dapat diimplementasikan dalam melatih keterampilan pemecahan masalah oleh peserta didik pada pembelajaran fisika, dibandingkan model pembelajaran yang lainnya.

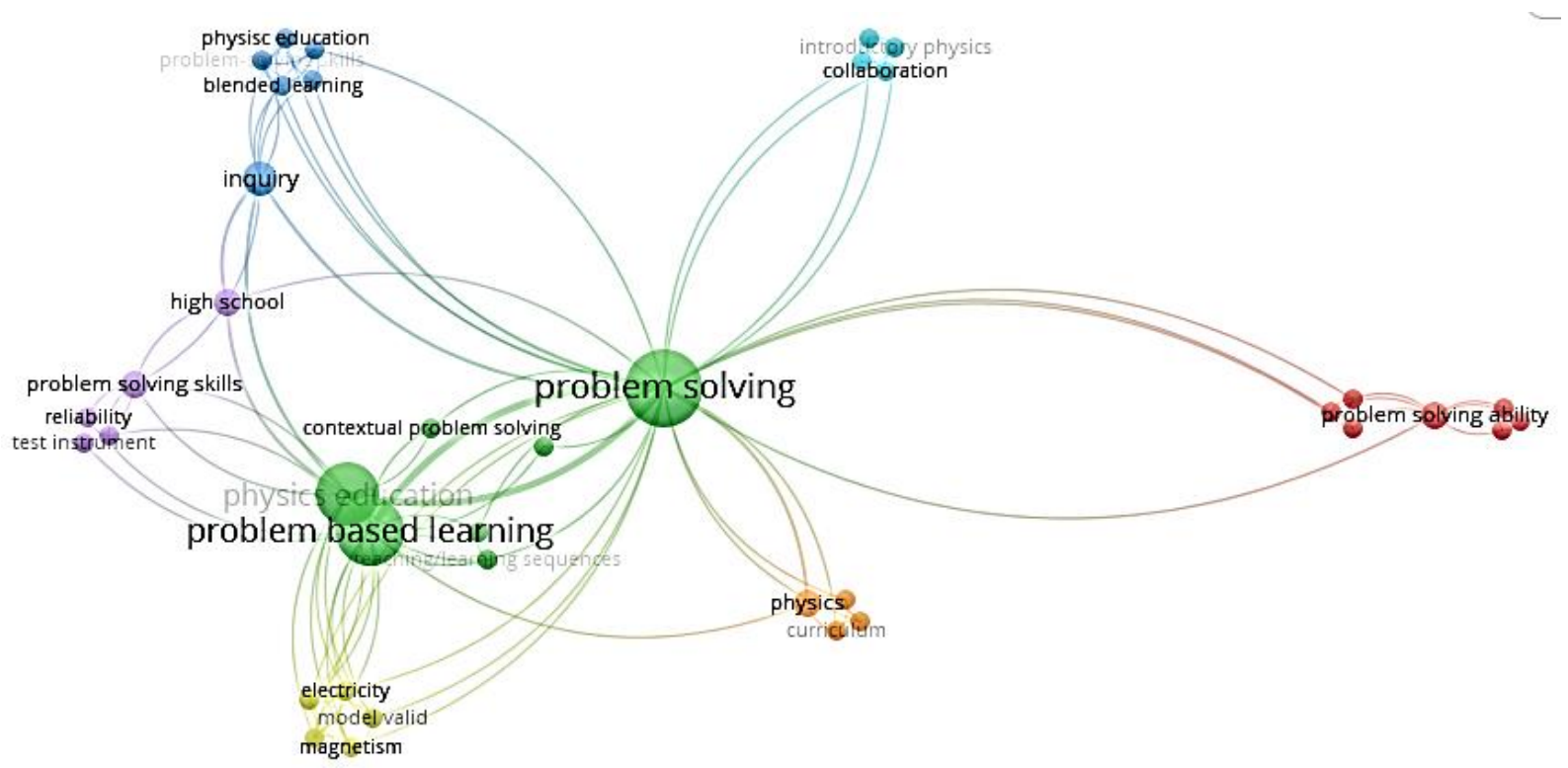

Gambar 3. Peta visualisasi network terhadap keyword

Gambar 4 dan Gambar 5 menunjukkan kata kunci yang memenuhi tujuan penelitian yaitu model pembelajaran yang dapat melatih keterampilan pemecahan masalah. Gambar 4 memperlihatkan penggunaan model PBL dalam upaya melatih dan meningkatkan keterampilan pemecahan masalah peserta didik terutama pada materi kelistrikan dan kemagnetan. Model PBL merupakan model titik awal pembelajaran berdasarkan masalah kontekstual, yang digunakan untuk dapat melatih keterampilan pemecahan masalah dalam pembelajaran fisika dan membuat peserta didik lebih interaktif, efektif, semangat dan 
termotivasi dalam proses belajar, sehingga penyampaian materi pembelajaran dapat tersampaikan dan tersalurkan dengan baik (Azninda. H et al, 2018; Iradat. R et al, 2017; Argaw et al, 2017). Materi bidang kelistrikan dan kemagnetan merupakan materi fisika yang sulit dipahami oleh peserta didik, karena peserta didik lebih memilih menghafalkan rumus matematis dibandingkan memahami konsep kelistrikan ataupun kemagnetan, selain itu gerak partikel pada kelistrikan dan kemagnetan tidak kasat mata yang membuat peserta didik kesulitan dalam memahami konsep tersebut (Almudi et al, 2016; Sabrina et al, 2018). Kurniawan. B R et al (2018) menyampaikan bahwa untuk mengukur keterampilan pemecahan masalah peserta didik pada pembelajaran fisika yang menggunakan model PBL, diperlukan adanya instrumen penilaian yang dapat dipercaya (reliability) sehingga dapat meminimalisir kesalahan hasil pengukuran. Model PBL cocok digunakan untuk memudahkan peserta didik memahami berbagai materi fisika dengan mengadaptasi sintaks yang sesuai model problem based learning $(P B L)$ di proses pembelajaran.

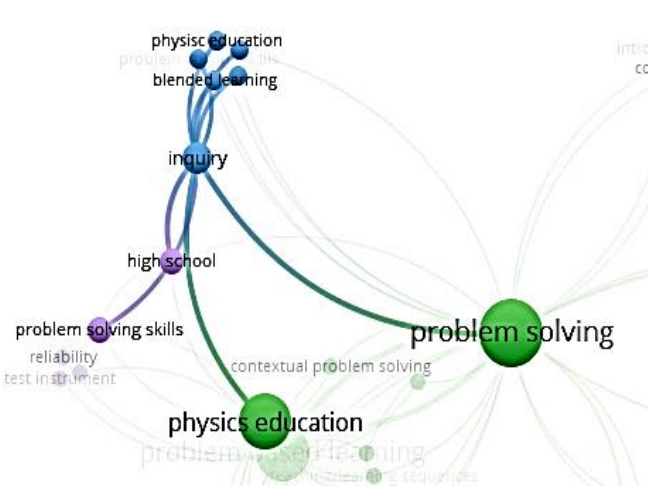

Gambar 4. Keterkaitan model pembelajaran PBL dalam pembelajaran fisika dan pemecahan masalah

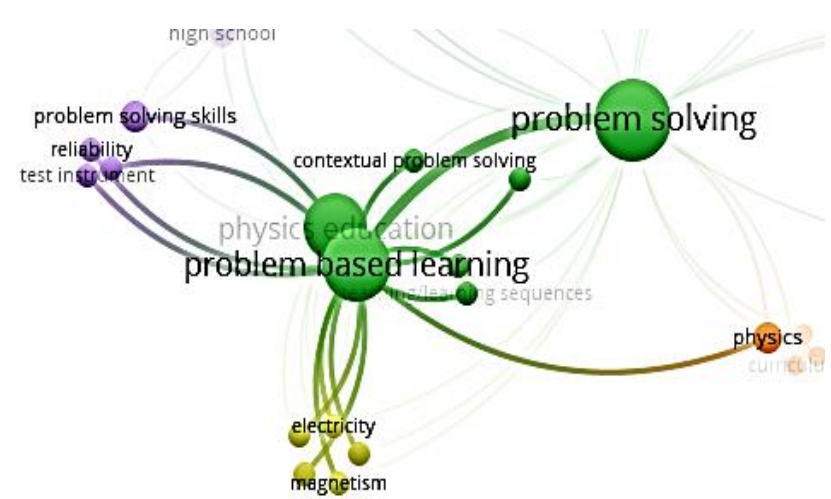

Gambar 5. Keterkaitan model pembelajaran inkuiri dalam pembelajaran fisika dan pemecahan masalah

Selain model problem-based learning (PBL), berdasarkan hasil penelitian terdapat model pembelajaran lain yang juga dapat digunakan untuk melatih keterampilan pemecahan masalah. Model pembelajaran ini ialah model pembelajaran inkuiri dengan pendekatan blended learning. Model pembelajaran inkuiri merupakan pembelajaran berbasis penyelidikan, yang mana peserta didik mencari sendiri jawaban dari permasalahan yang dihadapi secara individu maupun berkelompok (Aminullah, $\mathrm{R}$ et al, 2016). Pendekatan blended learning merupakan pendekatan yang secara umum menggunakan media berbasis teknologi digital dan teknologi informasi komunikasi (TIK) (Kurniawan. A et al, 2019). Proses pembelajaran fisika pada era sekarang tidak dapat jauh dari teknologi digital. Menurut analisis kata kunci, teknologi informasi dan komunikasi juga mendukung dan memudahkan ketercapaian keterampilan pemecahan masalah karena dalam praktiknya guru menggunakan perangkat TIK dalam melaksanakan proses pembelajaran. Semua pengetahuan dan konsep yang sulit untuk dipecahkan dapat diakses dengan cukup mudah dengan adanya internet. 
Tabel 2. Perangkat pembelajaran untuk melatih keterampilan pemecahan masalah tahun 20162020

\begin{tabular}{|c|c|c|c|c|}
\hline $\begin{array}{c}\text { Model } \\
\text { Pembelajaran }\end{array}$ & Materi Fisika & Penulis Artikel & $\begin{array}{c}\text { Pendekatan } \\
\text { Pembelajaran }\end{array}$ & $\begin{array}{c}\text { Media } \\
\text { Pembelajaran }\end{array}$ \\
\hline \multirow[t]{5}{*}{$\begin{array}{l}\text { Inquiry } \\
\text { Learning (IL) }\end{array}$} & $\begin{array}{l}\text { Termodinamika } \\
\text { (Teori Kinetik Gas) }\end{array}$ & $\begin{array}{l}\text { Kurniawan. A et } \\
\text { al, } 2019\end{array}$ & - & $\begin{array}{l}\text { Teknologi } \\
\text { (smartphone) }\end{array}$ \\
\hline & $\begin{array}{l}\text { Kelistrikan } \\
\text { (Induksi } \\
\text { elektromagnetik) }\end{array}$ & $\begin{array}{l}\text { Almudi. J et al, } \\
2016\end{array}$ & - & - \\
\hline & $\begin{array}{l}\text { Mekanika } \\
\text { (Momentum dan } \\
\text { Impuls) }\end{array}$ & $\begin{array}{l}\text { Aminullah. R et al, } \\
2020\end{array}$ & - & - \\
\hline & Mekanika (GLBB) & $\begin{array}{l}\text { Fitriani. N et al, } \\
2020\end{array}$ & - & - \\
\hline & - & $\begin{array}{l}\text { Herayanti. L et al, } \\
2020\end{array}$ & $\begin{array}{l}\text { Blended } \\
\text { Learning }\end{array}$ & - \\
\hline \multirow{11}{*}{$\begin{array}{l}\text { Problem } \\
\text { Based } \\
\text { Learning } \\
\text { (PBL) }\end{array}$} & $\begin{array}{l}\text { Mekanika } \\
\text { (Kinematika) }\end{array}$ & Argaw et al, 2017 & - & - \\
\hline & $\begin{array}{l}\text { Mekanika (Hk. } \\
\text { Newton) }\end{array}$ & $\begin{array}{l}\text { Sakhman. L et al, } \\
2019\end{array}$ & - & - \\
\hline & $\begin{array}{l}\text { Mekanika } \\
\text { (Momentum dan } \\
\text { Impuls) }\end{array}$ & $\begin{array}{l}\text { Abdulfattah. A et } \\
\text { al, } 2019\end{array}$ & - & - \\
\hline & $\begin{array}{l}\text { Mekanika (Fluida } \\
\text { Dinamis) }\end{array}$ & Song. Y, 2018 & - & - \\
\hline & $\begin{array}{l}\text { Mekanika (Gerak } \\
\text { Harmonik } \\
\text { Sederhana) }\end{array}$ & $\begin{array}{l}\text { Iradat. R et al, } \\
2017\end{array}$ & Laboratorium & $\begin{array}{l}\text { Teknologi } \\
\text { Virtual }\end{array}$ \\
\hline & $\begin{array}{l}\text { Kelistrikan } \\
\text { (Elektronika } \\
\text { Digital) }\end{array}$ & Jin. Y et al, 202 & - & $\begin{array}{l}\text { Teknologi } \\
\text { (Smartphone, } \\
\text { laptop) }\end{array}$ \\
\hline & Kelistrikan & $\begin{array}{l}\text { Shabrina et al, } \\
2018\end{array}$ & $\begin{array}{l}\text { Physics mobile } \\
\text { learning }\end{array}$ & $\begin{array}{l}\text { Teknologi } \\
\text { (laptop, } \\
\text { smartphone) }\end{array}$ \\
\hline & $\begin{array}{l}\text { Kelistrikan (Listrik } \\
\text { Magnet) }\end{array}$ & $\begin{array}{l}\text { Pandaengan. P et } \\
\text { al, } 2017\end{array}$ & - & - \\
\hline & Fisika Inti & $\begin{array}{l}\text { Raissi. M et al, } \\
2019\end{array}$ & - & - \\
\hline & - & $\begin{array}{l}\text { Mason. A et } \\
\text { al,2016 }\end{array}$ & - & - \\
\hline & - & $\begin{array}{l}\text { Putra. A et al, } \\
2018\end{array}$ & - & - \\
\hline $\begin{array}{l}\text { Project } \\
\text { Based } \\
\text { Learning } \\
(P j B L)\end{array}$ & Mekanika (Fluida) & $\begin{array}{l}\text { Retno. N H D et } \\
\text { al, } 2019\end{array}$ & - & - \\
\hline \multirow[t]{2}{*}{$\begin{array}{l}\text { Causal } \\
\text { Learning }\end{array}$} & $\begin{array}{l}\text { Kelistrikan } \\
\text { (Rangkaian Listrik } \\
\text { Tertutup) }\end{array}$ & $\begin{array}{l}\text { Rokhmat. J et al, } \\
2019\end{array}$ & $\begin{array}{l}\text { Causalistic } \\
\text { Thinking } \\
\text { Approach }\end{array}$ & - \\
\hline & Termodinamika & $\begin{array}{l}\text { Rokhmat. J et al, } \\
2017\end{array}$ & & - \\
\hline \multirow[t]{2}{*}{$\begin{array}{l}\text { Collaborative } \\
\text { Learning }\end{array}$} & Kelistrikan & $\begin{array}{l}\text { Olaniyan. A et al, } \\
2017\end{array}$ & - & $\begin{array}{l}\text { Teknologi } \\
\text { (Smartphone } \\
\text { Android) } \\
\end{array}$ \\
\hline & - & $\begin{array}{l}\text { Patandean. A et } \\
\text { al, } 2017\end{array}$ & - & - \\
\hline
\end{tabular}


Tinjauan secara spesifik terhadap model pembelajaran yang diterapkan pada 21 artikel terpilih, dalam upaya melatihkan dan meningkatkan keterampilan pemecahan masalah peserta didik berikut perangkat pembelajarannya terangkum dalam Tabel 2 . Sebagian penulis artikel tidak mencantumkan pembelajaran yang digunakan untuk melatih keterampilan pemecahan masalah pada kata kunci (keyword), sehingga dilakukan tinjauan lebih lanjut dalam artikel tersebut. Ditemukan model pembelajaran lain yang mampu melatih keterampilan pemecahan masalah, yaitu model pembelajaran kausalistik, pembelajaran kolaboratif, dan project based learning (PjBL). Model pembelajaran kausalistik merupakan model pembelajaran sebab akibat yang dikembangkan dan dirancang berdasarkan pada pendekatan berpikir kausalitik dan analitik, yaitu guru mengarahkan peserta didik menganalisis setiap fenomena fisika, serta menyusun argumen untuk menjelaskan bagaimana kondisi setiap unsur penyebab sehingga secara bersama-sama menghasilkan suatu akibat dari fenomena fisika (Rokhmat et al, 2019).

Pembelajaran kolaboratif merupakan pembelajaran yang melibatkan peserta didik untuk bekerja sama dalam suatu kelompok untuk menyelesaikan masalah, melengkapi tugas atau menghasilkan suatu produk yang dapat mengembangkan keaktifan peserta didik dalam kegiatan belajar mengajar (Dermawan. A, 2014). PjBL merupakan pembelajaran yang berpusat pada proses dan berfokus pada masalah, keunggulan dan karakteristik dari pembelajaran $\mathrm{PjBL}$ yaitu peserta didik merancang sebuah masalah dan mencari penyelesaiannya sendiri, hal itu dapat melatih peserta didik bertanggung jawab dalam mengelola informasi yang telah dilakukan (Kristanti. Y D et al, 2017).

Berdasarkan uraian mengenai model pembelajaran dapat diketahui sebagian besar model pembelajaran yang dapat melatih keterampilan pemecahan masalah, yaitu model pembelajaran dengan pendekatan berbasis saintifik. Model pembelajaran berbasis pendekatan saintifik tersebut adalah PBL, PjBL, pembelajaran kolaboratif, dan pembelajaran inkuiri. Pembelajaran dengan pendekatan saintifik menuntut peserta didik berpikir sistematis dan kritis dalam upaya memecahkan permasalahan dengan 6 tahapan, yaitu mengamati, menanya, mengumpulkan informasi, melakukan percobaan, mengolah data, serta mengomunikasikan hasil (Septian. N et al, 2018; Setiawan. A R, 2019). Pembelajaran saintifik berpusat pada peserta didik (student centered learning) dan berorientasi pada kerja sama antar kelompok, sehingga memberi kesempatan kepada peserta didik untuk terlibat secara aktif dalam pembelajaran di kelas yang diharapkan dapat memaksimalkan proses pembelajaran dan hasil belajar (Kusuma. R G T, 2019). Guru maupun calon guru dapat menggunakan salah satu perangkat pembelajaran yang terdapat pada Tabel 2 untuk melatih keterampilan pemecahan masalah yang disesuaikan dengan kondisi peserta didik dan tujuan pembelajaran. Melalui berbagai macam perangkat pembelajaran tersebut, diharapkan materi pembelajaran fisika dapat tersampaikan dengan baik dan tujuan pembelajaran dapat terpenuhi.

Tabel 2 dapat memberi informasi mengenai materi yang dapat digunakan untuk melatih keterampilan pemecahan masalah pada pembelajaran fisika, yaitu materi tentang mekanika, termodinamika, kelistrikan, dan fisika inti, karena peserta didik dapat menemui konsep mengenai materi tersebut dalam kehidupan sehari-hari. Tabel 2 juga memberi informasi mengenai materi yang paling sering digunakan dalam penelitian untuk melatih keterampilan pemecahan masalah pada pembelajaran fisika yaitu materi tentang Mekanika, yang ditemukan pada 7 artikel yang telah di analisis. Mekanika merupakan salah satu konsep dasar dengan topik yang sangat luas dan cukup rumit (Safriana et al, 2018). Sebelum peserta didik melanjutkan pada bab selanjutnya yaitu optik, termodinamika, dan kelistrikan maupun 
kemagnetan, materi tentang mekanika merupakan materi dasar yang perlu dilatihkan dalam memecahkan masalah, karena pada materi tentang mekanika terdapat konsep yang sering ditemui dalam kehidupan sehari-hari. Peserta didik yang sejak awal sudah terlatih memecahkan masalah fisika, maka pada pembelajaran fisika selanjutnya peserta didik akan merasa lebih mudah dalam memecahkan berbagai persoalan fisika.

Penemuan lain pada Tabel 2 yaitu media pembelajaran yang paling banyak digunakan untuk membantu melatih keterampilan pemecahan masalah adalah media berbasis teknologi, yang terdapat juga pada analisis keterkaitan kata kunci pada gambar 5 mengenai teknologi informasi dan komunikasi yang dapat membantu peserta didik untuk memecahkan masalah. Proses pembelajaran fisika abad 21 tidak dapat dipisahkan dari teknologi. Peserta didik terbiasa menggunakan smartphone maupun laptop yang terhubung dengan jaringan internet dalam kehidupan sehari-hari, sehingga guru dapat memanfaatkan media teknologi untuk mengembangkan keterampilan pemecahan masalah pada pembelajaran fisika. Menurut Olaniyan. A et al, 2017 media teknologi menjadikan peserta didik lebih mudah untuk menemukan pengetahuan dan konsep yang sulit untuk dipecahkan dari berbagai sumber dengan bantuan media teknologi untuk memecahkan masalah fisika dengan bantuan jaringan internet.

Berdasarkan uraian mengenai praktik pembelajaran fisika yang dapat melatih keterampilan pemecahan masalah, model pembelajaran yang paling tepat yaitu model PBL dengan bantuan media teknologi. Model PBL dan bantuan media teknologi membantu peserta didik untuk memiliki keterampilan memecahkan masalah dalam situasi nyata dan dapat membangun pengetahuannya sendiri melalui aktivitas belajar yang akan memudahkan peserta didik menggali informasi secara mandiri. Model PBL berfokus pada masalah sehingga peserta didik tidak perlu mempelajari materi yang tidak berhubungan dengan masalah konstektual, yang akan mengurangi beban peserta didik dengan menghafal. Pembelajaran menggunakan model PBL lebih berpusat kepada peserta didik, sehingga media teknologi berperan penting untuk membantu peserta didik mencari informasi dari berbagai sumber dibandingkan hanya menunggu materi dari guru. Peserta didik yang terlatih memecahkan permasalahan akan lebih mudah dalam menyelesaikan berbagai permasalahan fisika.

Peninjauan ulang 21 artikel memberikan informasi bahwa 11 dari 21 artikel menggunakan model PBL untuk melatih keterampilan pemecahan masalah pada pembelajaran fisika. 11 artikel yang menggunakan model PBL menyebutkan bahwa model PBL efektif digunakan untuk melatih keterampilan pemecahan masalah pada pembelajaran fisika. Peneliti menarik informasi, bahwa model PBL merupakan model yang tepat untuk melatih keterampilan pemecahan masalah pada pembelajaran fisika dibandingkan model pembelajaran yang lain, karena (1) model PBL menyediakan masalah yang dekat dengan kehidupan nyata dan mungkin terjadi dalam kehidupan nyata yang akan memudahkan peserta didik memahami konsep fisika, (2) model PBL mendorong peserta didik terlibat secara langsung dalam kegiatan pembelajaran, (3) model PBL mendorong penggunaan berbagai pendekatan terutama pendekatan saintifik, (4) model PBL memberi kesempatan peserta didik untuk membuat pilihan bagaimana dan apa yang akan dipelajarinya, (5) model PBL mendorong pembelajaran berbasis kolaborasi dan kerja sama antar kelompok, (6) model PBL membantu mencapai pendidikan yang berkualitas, dan (7) model PBL dirancang dan dikembangkan untuk meningkatkan keterampilan pemecahan masalah. 


\section{Penyebab Peserta Didik Kesulitan Memecahkan Masalah Fisika}

Tabel 3 menunjukkan beberapa penyebab dari rendahnya keterampilan pemecahan masalah peserta didik pada pembelajaran fisika di SMA. Untuk mengetahui penyebab kesulitan memecahkan masalah fisika, maka harus diketahui penyebab eksternal dari kesulitan tersebut, agar guru dapat memperbaiki model, metode, dan media pembelajaran yang akan digunakan. Dari 21 artikel yang dianalisis, terdapat 19 artikel yang memberikan penjelasan bahwa faktor eksternal merupakan faktor paling dominan yang menjadi penyebab kesulitan pemecahan masalah fisika. Faktor eksternal tersebut, antara lain setiap peserta didik memiliki pemikiran dan pengalaman yang berbeda dalam kehidupan sehari-hari, serta guru masih menggunakan metode pembelajaran konvensional yang menyebabkan kurangnya motivasi bagi peserta didik. Metode pembelajaran konvensional merupakan faktor utama dibandingkan faktor lain yang mempengaruhi peserta didik kesulitan memecahkan masalah, dikarenakan metode ini berpusat pada guru (teacher centered learning) yang menjadikan peserta didik lebih cenderung menghafal, serta sebagian besar peserta didik hanya mengandalkan informasi dari buku teks pembelajaran tanpa berusaha mencari informasi dari berbagai sumber, yang mengakibatkan sebagian besar peserta didik tidak memahami konsep dengan baik tentang apa yang telah disampaikan guru. Pemahaman konsep merupakan faktor penting untuk menyelesaikan permasalahan pada pembelajaran fisika tentang fenomena kehidupan sehari-hari

Pendapat lain menjelaskan adanya penyebab kesulitan pemecahan masalah fisika yang lainnya ialah buku teks pembelajaran yang hanya berisi persamaan matematis tanpa menjelaskan informasi secara detail, sehingga konsep dasar fisika tersebut agak sulit dipahami oleh peserta didik. Pada jurnal lain dijelaskan bahwa metode belajar peserta didik juga menjadi penyebab kesulitan keterampilan memecahkan masalah. Keberagaman peserta didik menunjukkan keberagaman berbagai metode belajar yang berbeda-beda, menjadi salah satu tantangan untuk mencapai tujuan pembelajaran yang utuh.

Tabel 3. Penyebab peserta didik mengalami kesulitan memecahkan masalah fisika

\begin{tabular}{|c|c|}
\hline $\begin{array}{l}\text { Penyebab kesulitan memecahkan } \\
\text { masalah fisika }\end{array}$ & Nama Penulis \\
\hline $\begin{array}{l}\text { Buku teks pembelajaran hanya berisi } \\
\text { persamaan matematis tanpa } \\
\text { menjelaskan informasi secara detail }\end{array}$ & $\begin{array}{l}\text { Almudí. J M et al, 2016; Argaw. A et al, } \\
\text { 2017; Song. Y, 2018; Shakhman. L et al, } \\
\text { 2019; Aminulloh. R, } 2020\end{array}$ \\
\hline $\begin{array}{l}\text { Guru masih menggunakan metode } \\
\text { pembelajaran konvensional }\end{array}$ & $\begin{array}{l}\text { Mason. A J et al, 2016; Iradat. R et al, } \\
\text { 2017; Pandiangan. P, 2017; Rokhmat. J } \\
\text { et al 2017; Putra. A et al, 2017; Retno. N } \\
\text { H D et al, 2019; Kurniawan. A et al, 2019; } \\
\text { Fitriani. N et al, 2020; Herayanti. L et al, } \\
\text { 2020; Jon. Y et al, 2020 }\end{array}$ \\
\hline Kurangnya motivasi & $\begin{array}{l}\text { Iradat, R. et al, 2017; Song, Y, 2018; } \\
\text { Abdulfattah, A et al 2019; Raissi, M 2019; } \\
\text { Rokhmat. J et al, 2019; Fitriani, N et al, } \\
2020\end{array}$ \\
\hline $\begin{array}{l}\text { Pengalaman dalam kehidupan sehari- } \\
\text { hari }\end{array}$ & $\begin{array}{l}\text { Abdulfattah, A et al, 2019; Retno, N H D } \\
\text { et al. } 2019\end{array}$ \\
\hline Metode belajar peserta didik & $\begin{array}{l}\text { Shakhman. L et al, 2019; Aminulloh. R et } \\
\text { al, } 2020\end{array}$ \\
\hline
\end{tabular}

\section{Simpulan dan Saran}

Berdasarkan hasil dan pembahasan yang telah dilakukan, topik penelitian praktik pembelajaran yang dapat melatih keterampilan pemecahan masalah pada pembelajaran fisika di SMA dengan menggunakan analisis bibliometrik, dapat disimpulkan bahwa 15 penulis artikel memenuhi empat indikator keterampilan pemecahan masalah menurut G. Polya, yaitu 
memahami masalah, merencanakan penyelesaian, menyelesaikan masalah sesuai rencana, dan melakukan pengecekan kembali terhadap semua langkah dan melakukan evaluasi. Berdasarkan hasil kajian studi literatur didapatkan beberapa rekomendasi model pembelajaran yang dapat melatih keterampilan pemecahan masalah, yaitu model pembelajaran dengan pendekatan saintifik yang menekankan pada student centered learning dan bantuan media teknologi, seperti PBL, pembelajaran inkuiri, PjBL, dan pembelajaran kolaboratif, terutama pada materi mekanika. Hasil lain didapatkan faktor utama penyebab peserta didik kesulitan memecahkan masalah fisika adalah guru masih menggunakan metode pembelajaran konvensional.

\section{Daftar Pustaka}

Abdulfattah, A; Supahar. 2019. The development of high school physics problem solving skills test instruments based problem-based learning. Journal for the Education of Gifted Young Scientists Vol 7 (4) 1037-1052.

Almudí, J M; Zuza, K; Guisasola, J. 2016. Learning of electromagnetic induction theory in general physics university courses. A teaching based on guided problem solving. Ensenanza deXlas Ciencias Vol 34 (2) pages 7-24.

Amanah. P D, Harjono. A, Gunada. I W. 2017. Kemampuan pemecahan masalah dalam fisika dengan pembelajaran generatif berbantuan scaffolding dan advance organizer. Jurnal Pendidikan Fisika dan Teknologi Vol.3 No. 1.

Aminulloh, R; Suhendra; M, Ristiana. 2020. Improvement physics problem's solving ability of senior high school students by using inquiry models with everyone is a teacher here strategy. Journal of Physics: Conference Series Vol 1657 (1).

Argaw, A: Haile, B; Ayalew, B; Kuma, S. 2017. The effect of problem based learning (PBL) instruction on students'motivation and problem solving skills of physics. Eurasia JournalXof Mathematics, Science and Technology Education Vol 13 (3) 857-871.

Azizah. R, Yuliati. L, Latifah. E. 2015. The physic problem solving difficulties on high school student. Jurnal Penelitian Fisika dan Aplikasinya (JPFA) Vol 5 (2)

Azninda. H, Setyarsih. W. 2018. Penerapan model pembelajaran problem based learning menggunakan strategi self regulated learning untuk meningkatkan kemampuan problem solving peserta didik. Inovasi Pendidikan Fisika Vol 07 (2) 347-352

Cahyani. H, Setyawati. R W. 2016. Pentingnya peningkatan kemampuan pemecahan masalah melalui pbl untuk mempersiapkan generasi unggul menghadapi MEA. Seminar Nasional Matematika X Universitas Negeri Semarang 2016

Dermawan. A. 2014. Keefektifan collaborativeXlearning berbasisXquiz edutainmentXterhadap ketuntasan hasil belajar. Chemistry in Education Vol 3 (1).

Destalia. L, Suratno, Aprilya. S H. 2014. Belajar melalui penerapan pembelajaran berbasis masalah (PBM) dengan metode eksperimen pada materi pencemaran lingkungan. Saintifika Vol. 3 (4) 213-224.

Docktor, J L, Dornfeld, J, Frodermann, E, Heller, K, Hsu, L, Jackson, K. A,Yang, J. 2016. Assessing student written problem solutions: A problem-solving rubric with application to introductory physics. Physical Review Physics Education Research, 12(1), 1-18.

Iolanessa. L, Kaniawati. I, Nugraha. M G. 2020. Pengaruh model problem based learning (pbl) menggunakan pendekatan stem dalam meningkatkan keterampilan pemecahan masalah siswa SMP. WaPFi (Wahana Pendidikan Fisika) 2020, Vol.5 No.1:113-117

Iradat, R; Alatas, F. 2017. The implementation of problem-solving based laboratory activities to teach the concept of simple harmonic motion in senior high school. Journal of Physics: Conference Series Vol 895 (1). 
Jayadiningrat. M G, Ati. E K. 2018. Peningkatan Keterampilan Memecahkan Masalah Melalui Model Pembelajaran Problem Based Learning (Pbl) Pada Mata Pelajaran Fisika. Jurnal Pendidikan Fisika Indonesia Vol 2 (1) 1-10.

Kristanti. Y D, Subiki, Handayani. R D. 2016. Model pembelajaran berbasis proyek (project based learning model) pada pembelajaran fisika di SMA. Jurnal Pembelajaran Fisika, Vol. 5 (2) $122-128$

Kurniawan, A; Suhandi, A; Kaniawati, I. 2019. Effect of application of dilemmatic problem solving oriented learning model in physics teaching on improvement decision making skills senior high school students. Journal of Physics: Conference Series Vol 1157 (3).

Kurniawan. B R, Taqwa. M R A. 2018. Pengembangan instrumen tes kemampuan pemecahan masalah fisika pada materi listrik dinamis. Jurnal Pendidikan, Vol 3 (11) 1451-1457.

Kusuma. R G T. 2019. Peningkatan Kemampuan Berfikir Kritis Mahasiswa Tadris IPA Melalui Pendekatan Saintifik Pada Mata kuliah IPA Terpadu. Indonesian J. Integr. Sci. Education Vol 1 (1)

Lestari. P E, Purwanto. A, Sakti. I. 2019. Pengembangan Instrumen Tes Keterampilan Pemecahan Masalah Pada Konsep Usaha dan Energi di SMA. Jurnal kumparan fisika, Vol 2 (30) 161-168.

Nuryudi. (2016). Analisis bibliometrika islam: studi kasus dokumentasi publikasi ilmiah di UIN Syarif Hidayatullah Jakarta. Al-Maktabah: Jurnal Komunikasi dan Informasi Perpustakaan. 15 (1), 41-55.

Nusaila, Siti \& Farida. 2015. Problem solving strategy in balanced forces. International Journal of Business and Social Science, 6(8), 94-98

Putra, A; Masril, M; Yurnetti, Y. 2018. Planning model of physics learning in senior high school to develop problem solving creativity based on national standard of education. IOP Conference Series: Materials Science and Engineering Vol 335 (1).

Ratnaningdyah. D. 2017. Upaya melatihkan kemampuan pemecahan masalah melalui pembelajaran fisika dengan model cooperative problem solving (CPS). Jurnal IImu Pendidikan Fisika Vol 2 (1) 1-3

Retno, N H D; Sunarno, W; Marzuki, A. 2019. Influence of physics problem-solving ability through the project based learning towards vocational high school students' learning outcomes. Journal of Physics: ConferenceXSeries Vol 1307 (1).

Rohkmat, J., Marzuki, Wahyudi, \& Putrie, S. D. (2019). Physics-informed neural networks: A deep learning framework for solving forward and inverse problems involving nonlinear partial differential equations. Journal of Turkish Science Education Vol 16 (4) 569-579..

Ryan, Q. X., Frodermann, E., Heller, K., Hsu, L., \& Mason, A. 2016. Computer problem-solving coaches for introductory physics: design and usability studies. Physical Review Physics Education Research, 12(1), 10105

Safriani, Fatmi. N. 2018. Analisis miskonsepsi materi mekanika pada mahasiswa calon guru melalui force concept inventory dan certainty of response index. Jurnal Pendidikan Sains Indonesia. 6 (2), 90-94

Septina. N, Farida, Komarudin. 2018. Pengembangan lembar kerja siswa dengan pendekatan saintifik berbasis kemampuan pemecahan masalah. Jurnal Pemikiran dan Penelitian Pendidikan Vol 6 (2)

Setiawan. A R. 2019. Peningkatan literasi saintifik melalui pembelajaran biologi menggunakan pendekatan saintifik. Journal of Biology Education Vol 2 (1) 1-13.

Shabrina; Kuswanto, H. 2018. Android-assisted mobile physics learning through Indonesian batik culture: Improving students' creative thinking and problem solving. International Journal of Instruction Vol 11 (4) 287-302. 
Shute, V. J., Wang, L., Greiff, S., Zhao, W., \& Moore, G. 2016. Computers in human behavior measuring problem solving skills via stealth assessment in an engaging video game. Computers in Human Behavior, 63, 106-117.

Sidiq, Muhaemin. 2019. Panduan analisis bibliometrik sederhana. DOI: 10.13140/RG.2.2.15688.37125

Supeno, Subiki, Laili Widya Rohma.2018. Students' ability in solving physics problems on Newtons' law of motion. Jurnal IImiah Pendidikan Fisika Al-BiRuNi 07 (1) (2018) 59-70.

Suprapto. N, Sukarmin, Rinie Pratiwi Puspitawati, Erman, Dian Savitri, Chih-Hsiung K. 2020. Research trend on technological pedagogical content knowledge (TPACK) through bibliometric analysis (2015-2019)

Yulianingsih, S, Kurnia. D, Julia. J. 2020. Pemetaan sistematik dalam topik kajian problem posing berdasarkan analissis bibliometrik. Jurnal Pena IImiah: Vol 3, No 2 (2020).

Yulianingsih. K A, Sukarsa. K G, Suciptawati. L P. 2020. Penerapan regresi poisson untuk mengetahui faktor-faktor yang memengaruhi jumlah siswa SMA/SMK yang tidak lulus UN di Bali. e-Jurnal Matematika Vol. 1 (1) 59-63.

Yusuf. B B. 2018. Konsep dan Indikator Pembelajaran Efektif. Jurnal Kajian Pembelajaran dan Kelimnuwan Vol 1 (2) 13-20.

Zunanda. M, Sinulingga. K. 2017. Pengaruh model pembelajaran berbasis masalah dan kemampuan berpikir kritis terhadap keterampilan pemecahan masalah fisika siswa SMK. Jurnal Pendidikan Fisika Vol. 4 (1). 